\title{
Dezinternacjonalizacja w handlu detalicznym - model teoretyczny
}

Grzegorz Karasiewicz*

\section{Wprowadzenie - luka badawcza, cel i metodyka badawcza}

Problematyka dezinternacjonalizacji w handlu detalicznym pojawiła się w badaniach naukowych i publikacjach na początku XXI w. (Godley, Fletcher 2001; Alexander, Quin 2002; Burt i inni 2003; Burt i inni 2004; Wrigley, Currah 2003; Palmer 2004; Alexander i inni 2005; Palmer 2005; Grzesiuk 2006a; Grzesiuk 2006b; Palmer, Quinn 2007; Burt i inni 2008; Cairns i inni 2008; El-Amir, Burt 2008; Cairns i inni 2010; Grzesiuk 2016). Wiązało się to ze znaczącym wzrostem stopnia zaangażowania przedsiębiorstw handlu detalicznego w operacje zagraniczne, który rozpoczął się pod koniec lat 80 . XX w. (w Polsce od początku lat 90. XX w.). Część inwestycji na rynkach zagranicznych nie osiągnęła zamierzonych celów rynkowych i finansowych, stąd decyzje o wycofaniu się z danego rynku zagranicznego (Cairns i inni 2010). Dezinternacjonalizację można zdefiniować następująco: jako sprzedaż (lub likwidacje) jednostek handlu detalicznego (całego formatu lub też części sklepów) podmiotu prowadzacego działalność na rynkach zagranicznych (Burt i inni 2003; Burt i inni 2004; Alexander i inni 2005; Benito 2005).

Badania dotyczące dezinternacjonalizacji w handlu detalicznym można podzielić na dwie grupy. Pierwszą stanowią badania oparte na bazach danych umożliwiających określenie skali i zakresu procesów dezinternacjonalizacji w handlu detalicznym (Godley, Fletcher 2001; Burt i inni 2004; Alexander i inni 2005). Do kluczowych ustaleń można zaliczyć następujące:

1. dezinwestycja z rynku zagranicznego przyjmuje różne formy, ale większość jest związana z wyjściem danego podmiotu (formatu handlu detalicznego) z rynku geograficznego (Godley, Fletcher 2001; Burt i inni 2004; Alexander i inni 2005);

\footnotetext{
* Grzegorz Karasiewicz - prof. dr hab., Uniwersytet Warszawski, Wydział Zarządzania, Katedra Marketingu,karas@wz.uw.edu.pl.
} 
2. im wyższy stopień internacjonalizacji handlu detalicznego, tym większa liczba decyzji związanych z wyjściem z danego rynku geograficznego (Godley, Fletcher 2001; Burt i inni 2004; Alexander i inni 2005);

3. czas wyjścia z rynku zagranicznego jest w dużym stopniu uzależniony od specyfiki towarów oferowanych przez przedsiębiorstwa handlowe lub/i format handlu (w przypadku artykułów spożywczych krótszy niż w przypadku innych towarów) (Godley, Fletcher 2001; Burt i inni 2004; Alexander i inni 2005);

4. dominujący udział $\mathrm{w}$ procesach dezinternacjonalizacji mają podmioty, które wchodziły na rynki zagraniczne za pomocą strategii wejścia - spółki joint venture i przejęcia (Burt i inni 2004).

Druga grupa badań jest związana ze studiami przypadków opisującymi konkretne procesy wyjścia z danego rynku zagranicznego. Można do nich zaliczyć następujące studia przypadków: Marks \& Spencer (Burt i inni 2002), Tesco (Palmer 2004; Palmer 2005), Arcadia (Alexander, Quinn 2002), Ahold (Wrigley, Currach 2003; Palmer, Quinn 2007) i Home Depot (Bianchi, Arnold 2004, Bianchi, Ostale 2006), Sainsbury (El-Amir, Burt 2008). Badania te wskazują na dwa istotne czynniki wpływające na decyzje o wyjściu z danego rynku geograficznego. Pierwszy z nich ma charakter zewnętrzny - brak dostosowania działalności do specyfiki danego rynku geograficznego. Drugi czynnik to czynnik wewnętrzny, związany z rolą kadry zarządzającej. Na podstawie przeglądu literatury lukę badawczą można zdefiniować następująco: brak modelu teoretycznego przedstawiającego procesy dezinternacjonalizacji w handlu detalicznym opierającego się o teorię.

Celem publikacji jest przedstawienie modelu dezinternacjonalizacji w handlu detalicznym opierającego się na założeniach teorii legitymizacji oraz wskazanie kierunków dalszych badań. Artykuł na charakter koncepcyjny i opiera się na krytycznej analizie literatury przedmiotu.

\section{Teoria legitymizacji - istota, wymiary, założenia i działania}

Teoria legitymizacji jest rozszerzeniem teorii instytucjonalnej, która opiera się na założeniu, że zachowania i decyzje przedsiębiorstw są determinowane przez instytucje. Przedsiębiorstwa są „osadzone” we własnych wewnętrznych instytucjach (struktury, standardy, praktyki ukształtowane w przeszłości) (Meyer, Rowan 1977) oraz w instytucjach zewnętrznych, związanych z podmiotami funkcjonującymi w otoczeniu zewnętrznym, tj. $\mathrm{z}$ dostawcami, klientami, konkurentami i podmiotami tworzącymi regulacje (DiMaggio, Powell 1983). Kluczowe pojęcie w teorii instytucjonalnej może zostać zdefiniowane następująco: instytucja składa się z poznawczych, normatywnych i regulacyjnych struktur i działań prowadzacych do stabilności [przedsiębiorstwa] $i$ zrozumienia zachowań spolecznych. In- 
stytucje sa ksztaltowane przez różne nośniki: kultury, struktury i procedury oraz działaja na wielu poziomach weryfikacji (Scott 1995, s. 33).

Legitymizacja to dostosowanie podmiotu do instytucji wewnętrznych i zewnętrznych. Legitymizacja oznacza generalne postrzeganie lub założenie, że działania jednostki [przedsiębiorstwa] sa pożadane, właściwe lub odpowiednie w ramach jakiegoś społecznie skonstruowanego systemu norm, wartości, przekonań i definicji (Suchman 1995, s. 574).

Można wyróżnić różne typologie wymiarów legitymizacji (Diez-Martin i inni 2013) (zob. tabela 1). Pierwsza typologia pozwala zidentyfikować trzy wymiary: poznawczy, normatywny i regulacyjny (Scott 1995; Huang, Sternquist 2007). Wymiar poznawczy odnosi się do założenia, że decyzje i działania podmiotów są powiązane z przeszłymi decyzjami podjętymi przez dany podmiot i jego konkurentów. Oznacza to, że decyzje (działania), które przyniosły pozytywne skutki, są powielane, a decyzje (działania), które nie dały pożądanych efektów, nie są akceptowane (Forest, Mehier 2001; Huang, Sternquist 2007). Wymiar normatywny oznacza, że decyzje i działania podmiotu są determinowane moralnymi przekonaniami i zinternalizowanymi zobowiązaniami opierającymi się na wartościach społecznych i kulturowych danego społeczeństwa (Scott, Christensen 1995; Huang, Sternquist 2007). W przypadku wymiaru regulacyjnego istotne jest to, że decyzje i działania podmiotów są determinowane otoczeniem politycznym i prawnym charakterystycznym dla danego kraju (Scott 1995; Huang, Sternquist 2007).

Tabela1. Typologie wymiarów legitymizacji

\begin{tabular}{|c|c|c|c|}
\hline $\mathrm{Nr}$ typologii & 1 & 2 & 3 \\
\hline Wymiary & $\begin{array}{l}\text { Poznawczy } \\
\text { Normatywny } \\
\text { Regulacyjny }\end{array}$ & $\begin{array}{l}\text { Pragmatyczny } \\
\text { Moralny } \\
\text { Poznawczy }\end{array}$ & $\begin{array}{l}\text { Strategiczny } \\
\text { - zewnętrzny (komercyjny, } \\
\text { społeczny, inwestycyjny) } \\
\text { - wewnętrzny (akceptacyjny, } \\
\text { adaptacyjny) } \\
\text { Instytucjonalny } \\
\text { - polityczny } \\
\text { - prawny (regulacyjny) }\end{array}$ \\
\hline
\end{tabular}

Źródło: opracowanie własne.

W drugiej typologii wyróżnia się następujące wymiary: pragmatyczny, moralny i poznawczy (Schuman 1995; Diez-Martin i inni 2013). Wymiar pragmatyczny związany jest z przekonaniem, że decyzje i działania organizacji przyczynią się do osiągnięcia celów przez podmiot i będą korzystne dla interesariuszy wewnętrznych i zewnętrznych (Schuman 1995; Diez-Martin i inni 2013). Wymiar moralny dotyczy pozytywnej oceny decyzji i działań organizacji przez interesariuszy w odniesieniu do norm i wartości w danym społeczeństwie. Wymiar poznawczy oznacza, 
że decyzje i działania organizacji są zgodne z dotychczasowymi działaniami, które miały pozytywne skutki dla organizacji i jej interesariuszy.

W trzeciej typologii wyróżniono dwa wymiary: strategiczny i instytucjonalny (Turner 2011). Wymiar strategiczny zawiera elementy otoczenia zewnętrznego i wewnętrznego. W ramach otoczenia zewnętrznego można wyróżnić dostosowanie (Dacin i inni 2007) komercyjne (do zasad i warunków prowadzenia biznesu), relacyjne (akceptacja przez interesariuszy), społeczne (zgodność z normami i wartościami kulturowymi w danym społeczeństwie) i inwestycyjne (zgodność z oczekiwaną stopą zwrotu kosztów poniesionych przez instytucje finansowe). Wewnętrzne otoczenie określa akceptację decyzji i działań jednostki organizacji przez jej centralę i inne jednostki (Westney 1987) oraz adaptację wspólnych polityk, procedur i praktyk (Kostova, Zaheer 1983). Wymiar instytucjonalny jest związany z dostosowaniem organizacji do otoczenia politycznego i prawnego w danym kraju (Scott 1995; Turner 2011).

Kluczowe założenie teorii legitymizacji jest następujące: wysoki stopień legitymizacji podmiotu jest podstawą przetrwania oraz sukcesu rynkowego i finansowego, a także dostępu do zasobów (Meyer, Rowan 1977). Brak legitymizacji lub jej utrata prowadzi do niepowodzeń, a w skrajnym przypadku - do likwidacji podmiotu oraz utrudnienia dostępu do zasobów (Bianchi, Ostole 2006) (zob. rysunek 1).

Rysunek 1. Założenie teorii legitymizacji

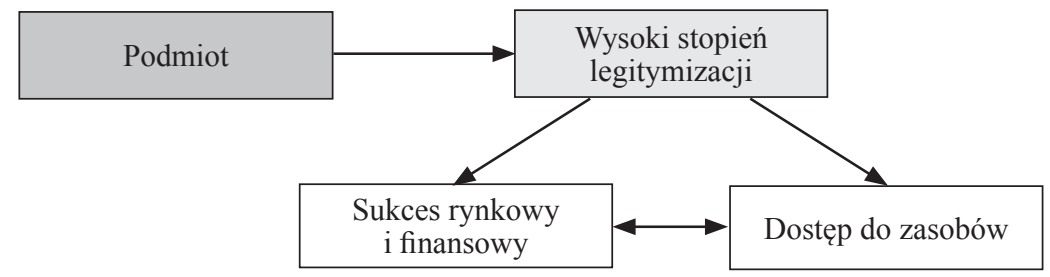

Źródło: opracowanie własne.

Działania przedsiębiorstwa odnoszące się do legitymizacji można podzielić na trzy grupy: pozyskanie, utrzymanie i odbudowę (Suchman 1995). Pozyskanie legitymizacji jest związane z:

1. rozpoznaniem otoczenia wewnętrznego i zewnętrznego,

2. wyborem interesariuszy,

3. określeniem ich oczekiwań i zasobów,

4. kategoryzacją priorytetów interesariuszy,

5. prowadzeniem działań pozwalających dostosować się do ich wymagań,

6. budowaniem wizerunku organizacji (marek).

Aby utrzymać legitymizację, należy monitorować efekty działalności organizacji w różnych wymiarach (np. osiąganie celów własnych oraz interesariuszy, 
dostosowanie do norm i wartości społecznych, wymagań regulacyjnych), ochronę priorytetów interesariuszy, równość wymiany (podejście win - win) i dobre praktyki. Odbudowa legitymizacji wiąże się z restrukturalizacją podmiotu. Punktem wyjścia jest identyfikacja przyczyn utraty legitymizacji, a następnie przeprowadzenie koniecznych zmian prowadzących do odbudowy legitymizacji. Zmiany te mogą dotyczyć: wymiany personelu (przede wszystkim decydentów), przekształceń strukturalnych, rekonfiguracji celów działania, przedefiniowania strategii i modyfikacji procedur działania. Decydenci (właściciele) organizacji mogą także uznać, że koszty naprawy legitymizacji są zbyt wysokie, i podjąć decyzję o wycofaniu się z działalności (sprzedaż lub likwidacja biznesu).

\section{Model dezinternacjonalizacji w handlu detalicznym}

Model dezinternacjonalizacji w handlu detalicznym to uproszczony obraz rzeczywistości opierający się na założeniach dotyczących: badanego obiektu, charakteru, podstawy teoretycznej oraz wewnętrznej struktury (elementów) i mechanizmu funkcjonowania. Obiekt badania w tym modelu definiowany jest $\mathrm{w}$ dwóch wymiarach - sektorowym i geograficznym. Wymiar sektorowy dotyczy handlu detalicznego, a właściwie formatu handlu detalicznego, który jest definiowany jako sposób prowadzenia sprzedaży detalicznej wynikajacej z oferowanego asortymentu, sposobu przedstawienia oferty klientowi, sposobu dostarczenia produktu klientowi, zakresu świadczonych ustug i zorganizowania czynników wytwórczych (Borusiak 2008, s. 171; Trojanowski 2013, s. 22-23). Wymiar geograficzny jest określony jako rynek danego kraju, gdyż on charakteryzuje się wysokim stopniem jednorodności instytucjonalnej (rynek właściwy geograficznie).

Model ma charakter deskryptywny - przedstawia zachowania podmiotów zagranicznych w sektorze handlu detalicznego w danym kraju po decyzji o wejściu na dany rynek geograficzny. Podstawą teoretyczną modelu jest teoria legitymizacji (Schuman 1995; Turner 2011). Model z jednej strony pomija pewne założenia i elementy tej teorii, które nie są istotne dla celów badawczych, a z drugiej strony ma charakter wzbogacający, gdyż odnosi się do specyficznej sytuacji badanego obiektu, w tym przypadku do formatów handlu detalicznego prowadzonych przez podmioty zagraniczne w danym kraju.

Struktura wewnętrzna modelu składa się z dwóch elementów odnoszących się do dalszego funkcjonowania przedsiębiorstwa zagranicznego (właściwie formatu) w sektorze handlu detalicznego na danym rynku geograficznym: determinanty dezinternacjonalizacji (wymiar analityczny) i opcje strategiczne (wymiar decyzyjny).

Wymiar analityczny (zob. rysunek 2). Decyzja o wycofaniu formatu handlu detalicznego z danego rynku geograficznego może wynikać z sytuacji na danym rynku geograficznym (w kraju goszczącym) i zmian dotyczących przedsiębiorstwa „matki”. 
Rysunek 2. Model dezinternacjonalizacji formatu handlu detalicznego - determinanty (wymiar analityczny)

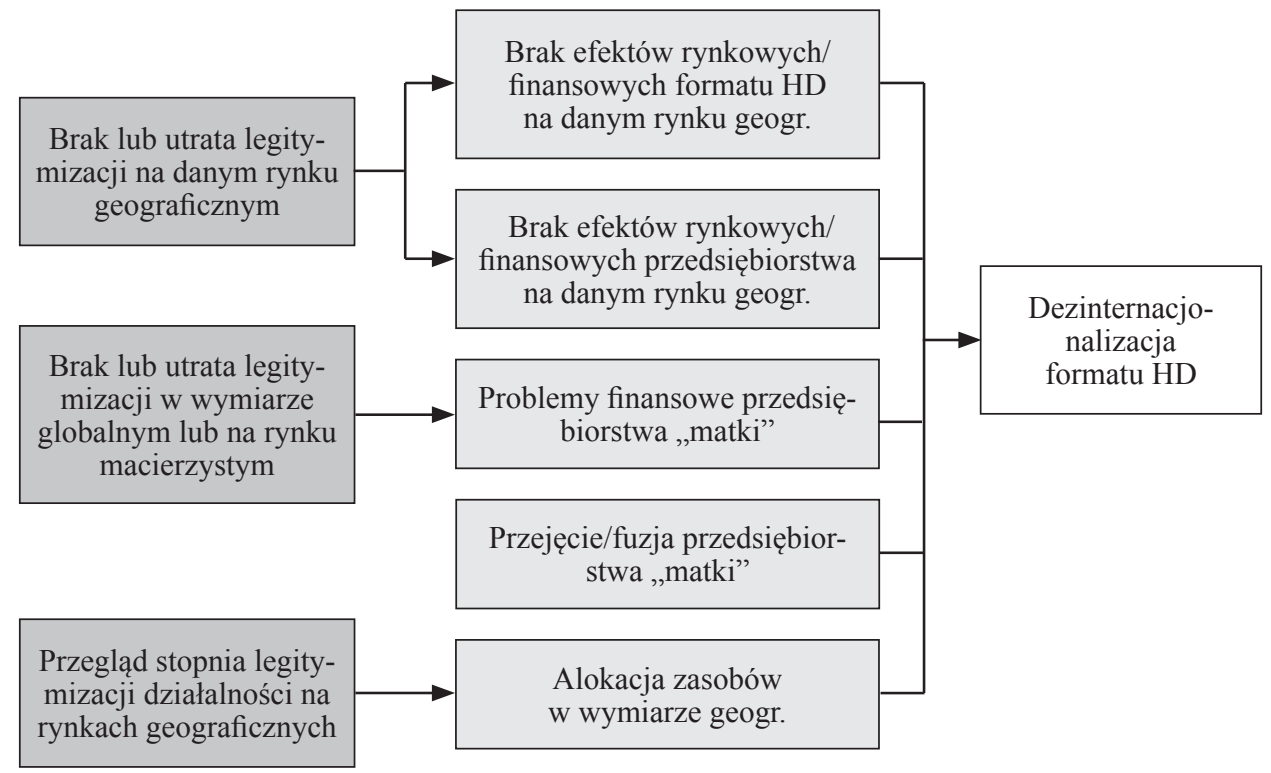

Legenda: HD - handel detaliczny.

Źródło: opracowanie własne.

Decyzja o dezinternacjonalizacji wynikająca z sytuacji na rynku geograficznym dotyczy braku lub utraty legitymizacji na danym rynku. Sygnałem ostrzegawczym jest nieosiągnięcie pożądanych efektów rynkowych i finansowych danego formatu HD (Duhaime, Grant 1984; Burt i inni 2003; Benito 2005; Burt i inni 2008). Kluczowe jest uzyskanie w perspektywie długookresowej pożądanej pozycji rynkowej oraz znaczącego udziału w rynku całkowitym lub danego formatu. Poziom udziału w rynku jest uzależniony od wielkości rynku kraju goszczącego. Pozycja rynkowa, determinowana udziałem $w$ rynku, ma bezpośredni wpływ na pozycję przetargową w relacji do dostawców, a tym samym określa opłacalność danego formatu HD. Decyzja o wycofaniu formatu HD z rynku geograficznego wynikająca z funkcjonowania przedsiębiorstwa „matki” związana jest z trzema zmianami.

1. Pierwsza z nich dotyczy przejęcia (lub fuzji) przedsiębiorstwa „matki” przez inny podmiot handlu detalicznego (czasami inwestora finansowego). Wówczas operacje na rynkach zagranicznych są poddawane ocenie strategicznej. W krajach goszczących, w których oba podmioty prowadzą operacje, następuje połącznie ich działalności. Nowy podmiot funkcjonuje pod nazwą formatu przedsiębiorstwa przejmującego. A w krajach goszczących, w których podmiot przejmujący prowadzi działalność związaną z innym formatem lub gdzie nie funkcjonuje przedsiębiorstwo przejmujące, możliwe są wszystkie opcje strategiczne. 
2. Druga zmiana jest związana z problemami finansowymi przedsiębiorstwa „matki” (Duhaime, Grant 1985; Burt i inni 2003). Ocena strategiczna formatów na poszczególnych rynkach zagranicznych może doprowadzić do sprzedaży części aktywów - najczęściej na rynkach zagranicznych o małej atrakcyjności i niskim stopniu legitymizacji - w celu uzyskania środków finansowych, które zostaną wykorzystane do poprawy sytuacji finansowej oraz rynkowej (przede wszystkim na rynku macierzystym).

3. Trzecia zmiana dotyczy alokacji zasobów w wymiarze geograficznym (Alexander, Quinn 2002; Burt i inni 2003; Grzesiuk 2016). Przedsiębiorstwa HD dążą do pozyskania dodatkowych środków finansowych do inwestowania w rynki geograficzne o wzrastającej atrakcyjności. Oznacza to w niektórych przypadkach pełną lub częściową dezinternacjonalizację z rynków geograficznych o niższej atrakcyjności (stopień legitymizacji).

Wymiar decyzyjny ${ }^{1}$ (zob. rysunek 3). Strategiczna ocena formatu HD na danym rynku geograficznym ma zróżnicowany charakter, a tym samym - stopień złożoności w poszczególnych przedsiębiorstwach. W przypadku tych podmiotów, które mają wyższy poziom umiejętności analitycznych (np. procedury, dostęp do informacji, przygotowanie pracowników), ocena jest bardziej złożona i czasochłonna. Można w niej zastosować analizę pozycji formatu HD wykorzystującą macierz legitymizacji strategicznej i instytucjonalnej (Turner 2011).

Rysunek 3. Model dezinternacjonalizacji formatu HD - opcje strategiczne (wymiar decyzyjny)

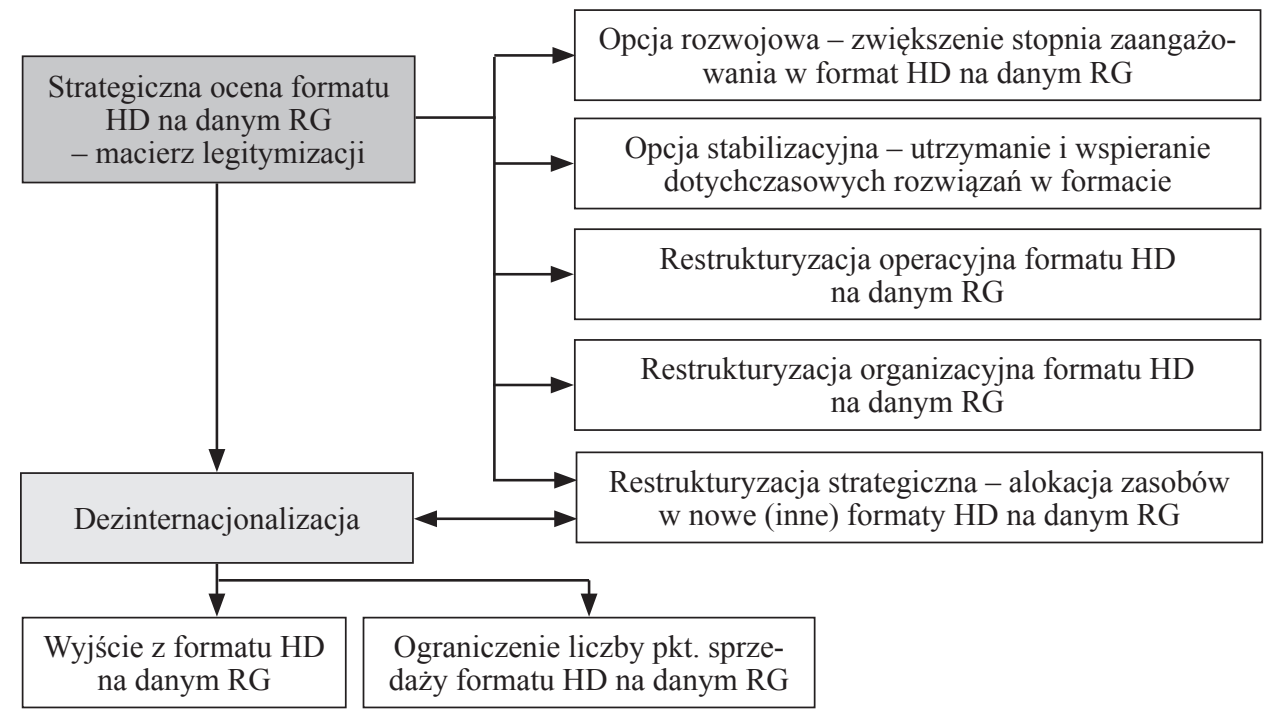

Legenda: HD - handel detaliczny, RG - rynek geograficzny.

Źródło: opracowanie własne.

${ }^{1}$ Wymiar decyzyjny przedstawia szerszy zakres opcji strategicznych przedsiębiorstwa handlu detalicznego, gdyż tylko jedna z sześciu opcji strategicznych jest wprost związana ze strategiczną decyzją o dezinternacjonalizacji. 
Omówiona ocena jest podstawą wyboru opcji strategicznej odnoszącej się do formatu handlu detalicznego w zależności od położenia w polach macierzy (zob. rysunek 4). Można wyróżnić opcje strategiczne: rozwojowe, stabilizacyjne, restrukturyzacyjne (operacyjna, organizacyjna i strategiczna) i dezinternacjonalizacyjne (Palmer 2004; Burt i inni 2003; Burt i inni 2004; Burt i inni 2008; Turner 2011).

Rysunek 4. Macierz legitymizacji

\begin{tabular}{|c|c|c|c|}
\hline & \multicolumn{2}{|c|}{ Legitymizacja instytucjonalna } \\
\hline & & Niska & Wysoka \\
\hline \multirow{2}{*}{ 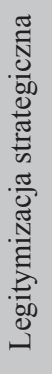 } & Wysoka & $\begin{array}{l}\text { pole } A \\
\text { Restrukturyzacja operacyjna } \\
\text { Restrukturyzacja organizacyjna }\end{array}$ & $\begin{array}{l}\text { pole } \mathrm{C} \\
\text { Opcja rozwojowa } \\
\text { Opcja stabilizacyjna }\end{array}$ \\
\hline & Niska & $\begin{array}{l}\text { pole } \mathrm{B} \\
\text { Dezinternacjonalizacja }\end{array}$ & $\begin{array}{l}\text { pole } \mathrm{D} \\
\text { Opcja rozwojowa } \\
\text { Restrukturyzacja strategiczna } \\
\text { Dezinternacjonalizacja }\end{array}$ \\
\hline
\end{tabular}

Źródło: opracowanie własne na podstawie Turner 2011.

W przypadku rozwojowej opcji strategicznej (Burt i inni 2003; Burt i inni 2004; Burt i inni 2008) przedsiębiorstwo decyduje się na zwiększenie stopnia zaangażowania. Jest to związane $\mathrm{z}$ otwieraniem nowych placówek handlowych (rozwój wewnętrzny) lub/i przejęciem całej sieci handlowej danego formatu należącej do podmiotu konkurencyjnego (lub też części sklepów). Decyzja taka zostanie podjęta $\mathrm{w}$ przypadku pozytywnej oceny strategicznej i dodatniej alokacji zasobów na dany format handlu w kraju goszczącym (pole C i D macierzy legitymizacji).

Opcja stabilizacyjna dotyczy utrzymania oraz wspierania dotychczasowych działań i rozwiązań, które przyniosły sukces rynkowy i finansowy. Format handlu detalicznego realizujący taką opcję staje się wzorcem dla działań danego pomiotu na innych rynkach zgodnie $\mathrm{z}$ wymiarem poznawczym legitymizacji (pole $\mathrm{C}$ macierzy legitymizacji).

Pozostałe opcje strategiczne (restrukturyzacyjna i dezinternacjonalizacji) są efektem mniej pozytywnej oceny strategicznej danego formatu handlu detalicznego na rynku zagranicznym. W ramach opcji restrukturyzacyjnej wyróżnia się: operacyjną, organizacyjną i strategiczną. Restrukturyzacja operacyjna (Burt i inni 2003; Burt i inni 2004; Burt i inni 2008) może być związana ze zmianami dotyczącymi: procedur zakupu, wyboru dostawców, rozwiązań logistycznych, oferowanego asortymentu towarów w placówkach handlowych, promocji sprze- 
dażowych, programu lojalnościowego, marki własnej pośrednika handlowego, polityki cenowej, aranżacji sklepów, godzin otwarcia sklepów (pole A w macierzy legitymizacji).

Restrukturyzacja organizacyjna (Burt i inni 2003; Palmer 2004; Burt i inni 2004; Burt i inni 2008) związana jest z przekształceniem własnych punktów sprzedaży (wszystkich lub części) na franchisingowe, ze zmianami udziałowymi w spółce joint venture, z pozyskaniem udziałowca (najczęściej z kraju goszczącego) do jednostki działającej na danym rynku geograficznym (pole A w macierzy legitymizacji).

Restrukturyzacja strategiczna (pole D w macierzy legitymizacji) dotyczy zwiększenia stopnia zaangażowania przedsiębiorstwa na danym rynku geograficznym w inne (często nowe) formaty handlu detalicznego na danym rynku geograficznym kosztem danego formatu (Burt i inni 2003; Burt i inni 2004; Burt i inni 2008).

Opcja dezinternacjonalizacji (Burt i inni 2003; Palmer 2004; Burt i inni 2004; Burt i inni 2008) polega na sprzedaży/zamknięciu części sklepów danego formatu lub sprzedaży, rzadziej likwidacji, całego formatu handlu detalicznego na danym rynku geograficznym (pole B w macierzy legitymizacji).

\section{Podsumowanie}

Teoria legitymizacji może być podstawą teoretyczną wyjaśnienia procesów deinternacjonalizacji w sektorze handlu detalicznego. Wymaga ona jednak weryfikacji empirycznej. Można w tym celu wykorzystać technikę wielu studiów przypadków. Kryterium doboru podmiotów do badania powinien stanowić stopień legitymizacji strategicznej i instytucjonalnej. Pierwsze badanie mogłoby opierać się na badaniu formatów handlu detalicznego jednego przedsiębiorstwa transnarodowego funkcjonującego w różnych krajach (co najmniej cztery przypadki odpowiadające polom macierzy legitymizacji). Drugie badanie mogłoby dotyczyć formatów handlu detalicznego z dwóch krajów o zróżnicowanej wycenie legitymizacji odpowiadające polom macierzy legitymizacji instytucjonalnej (co najmniej cztery przypadki odpowiadające polom macierzy legitymizacji).

\section{Bibliografia}

Alexander N., Quinn B. (2002), International retail divestment, „International Journal of Retail \& Distribution Management”, nr 30(2), s. 112-115.

Alexander N., Quinn B. i Cairns P. (2005), International retail divestment activity, „International Journal of Retail \& Distribution Management”, nr 33(1), s. 5-22.

Benito G.R.G. (2005), Divestment and international business strategy, „Journal of Economic Geography", nr 5(2), s. 235-251. 
Bianchi C.C., Arnold S.J. (2004), An institutional perspective on retail internationalization success: Home Depot in Chile, „International Review of Retail, Distribution and Consumer Research", nr 14(2), s. 149-169.

Bianchi C.C., Ostale E. (2006), Lessons learned from unsuccessful internationalisation attempts: examples of multi-international retailers in Chile, „Journal of Business Research”, nr 59(1), s. 140-147.

Borusiak B. (2008), Modele wzrostu przedsiębiorstw handlu detalicznego, Wydawnictwo Akademii Ekonomicznej w Poznaniu, Poznań.

Burt S.L., Mellahi K., Jackson T.P., Sparks L. (2002), Retail internationalisation and retail failure: issues from the case of Marks and Spencer, „International Review of Retail, Distribution \& Consumer Research", nr 12(2), s. 191-219.

Burt S.L., Dawson J., Sparks L. (2003), Failure in international retailing: Research propositions, „International Review of Retail, Distribution and Consumer Research", nr 13(4), s. 355-373.

Burt S.L., Dawson J., Sparks L. (2004), The international divestment activities of European grocery retailers, „European Management Journal”, nr 22(5), s. $483-492$.

Burt S.L., Dawson J., Sparks L. (2008), International retail divesment: Reviews, case studies and (e)merging agenda [w:] Swoboda B., Morschett D., Rudolph T., Schnedlitz P., Schramm-Klein H. (red.), European Retail Research, Gabler, Wiesbaden.

Cairns P., Doherty A.M., Alexander N., Quinn B. (2008), Understanding the International Retail Divestment Process, „Journal of Strategic Marketing”, nr 16(2), s. 111-128.

Cairns P., Quinn B., Alexander N., Doherty A.M. (2010), The Role of Leadership in International Retail Divestment, „European Business Review”, nr 22(1), s. 25-42.

Dacin M., Oliver C., Roy J. (2007), The legitimacy of strategic alliances: an institutional perspective, ,Strategic Management Journal”, nr 28(2), s. 169-189.

Diez-Martin F., Prado-Roman C., Blanco-Gonzales A. (2013), Beyond legitimacy: legitimacy types and organizational success, ,Management Decision", nr 51(10), s. 1954-1964.

DiMaggio P.J., Powell W.W. (1983), The iron cage revisited - institutional isomorphism and collective rationality in organizational fields, „American Sociological Review", nr 48(2), s. 147-160.

Duhaime I.M., Grant J.H. (1984), Factors influencing the deinvestment decision-making: evidence from a field study, „Strategic Management Journal", $\mathrm{nr}$ 5(4), s. 301-318.

El-Amir A., Burt S.L. (2008), Sainsbury's in Egypt: the strange case of Dr Jeykll and $\mathrm{Mr}$ Hyde?, „International Journal of Retail \& Distribution Management", nr 36(4), s. 300-322. 
Forest J., Mehier C. (2001), Simon on the concept of rationality [w:] Commons J.R., Herbert A. (eds.), ,Journal of Economic Issues”, nr 35(3), s. 591-605.

Godley A., Fletcher S.R. (2001), International Retailing in Britain 1850-1993, „Service Industries Journal”, nr 21(2), s. 31-46.

Grzesiuk A. (2006a), Międzynarodowe dywestycje w handlu detalicznym, „Marketing i Rynek”, nr 1, s. 28-34.

Grzesiuk A. (2006b), Dywestycje w internacjonalizacji handlu, „Ekonomika i Organizacja Przedsiębiorstwa", nr 2, s. 54-60.

Grzesiuk A. (2016), Dywestycje w handle detalicznym - doświadczenia rynku polskiego [w:] Sławińska M. (red.), Handel we współczesnej gospodarce. Nowe wyzwania, Wydawnictwo Uniwersytetu Ekonomicznego w Poznaniu, Poznań, s. 86-96.

Huang Y., Sternquist B. (2007), Retailers' foreign market entry decisions: an institutional perspective, „International Business Review”, nr 16(5), s. 613-629.

Kostova T., Zaheer S. (1999), Organizational legitimacy under conditions of complexity: the case of the multinational enterprise, „Academy of Management Review", nr 24(1), s. 64-81.

Meyer J.W., Rowan B. (1977), Institutionalized organizations - formal-structure as myth and ceremony, „American Journal of Sociology”, nr 83(2), s. 340-363.

Palmer M. (2004), International retail restructuring and divestment: the experience of Tesco, „Journal of Marketing Management”, nr 20(10), s. 1075-1105.

Palmer M. (2005), Retail multinational learning: a case study of Tesco, „International Journal of Retail and Distribution Management", nr 33(1), s. 23-48.

Palmer M., Quinn B. (2007), The nature of international retail divestment: insights from Ahold, „International Marketing Review”, nr 24(1), s. 26-44.

Scott W.R. (1995), Institution and organizations, Thousand Oaks (CA), Sage.

Scott W.R., Christensen S. (eds.) (1995), The institutional construction of organizations, Thousand Oaks (CA), Sage.

Sternquist B. (1997), International expansion of US retailers, „International Journal of Retail \& Distribution Management”, nr 25(8), s. 262-268.

Suchman M. (1995), Managing legitimacy: strategic and institutional approaches, „Academy of Management Review”, nr 20(3), s. 571-610.

Trojanowski M. (2013), Postawy konsumentów wobec sprzedaży wysytkowej w Polsce - ujęcie dynamiczne, Warszawa, Wydawnictwo Naukowe Wydziału Zarządzania Uniwersytetu Warszawskiego.

Tutner C. (2011), Coercive deinternationalisation and host institutional legitimacy, „European Business Review”, nr 23(2), s. 190-202.

Westney D. (1987), Imitation and innovation: the transfer of western organizational patterns to Meiki, Cambridge (MA), Harvard University Press.

Wrigley N., Currah A. (2003), The 'stresses' of retail internationalisation: lessons from Royal Ahold's experience in Latin America, „International Review of Retail, Distribution \& Consumer Research", nr 13(3), s. 221-243. 


\section{Streszczenie}

Artykuł przedstawia model teoretyczny procesów dezinternacjonalizacji w handlu detalicznym. Punktem wyjścia opracowania modelu jest przegląd literatury przedmiotu dotyczącej dezinternacjonalizacji w sektorze handlu detalicznego oraz teoria legitymizacji.

Słowa kluczowe: dezinternacjonalizacja, handel detaliczny, teoria legitymizacji

\section{Summary}

De-internationalisation in retail trade - a theoretical model

The article presents a theoretical model of the processes of de-internationalisation in retail trade. The starting point for the development of the model is a review of the literature on the subject of de-internationalisation processes in the retail trade sector and the theory of legitimisation.

Keywords: de-internationalisation, retail trade, theory of legitimacy

JEL: D02, L81 